\title{
PENGARUH IMPLEMENTASI KEBIJAKAN PEMERINTAH DAERAH TERHADAP EFEKTIVITAS PERUBAHAN JARINGAN TRAYEK ANGKUTAN UMUM DI KABUPATEN CIANJUR
}

\author{
Ayu Ayda Lestari ${ }^{1}$, Toto Kushartono ${ }^{2}$, Arlan Siddha ${ }^{3}$ \\ 1,2,3 Program Studi Ilmu Pemerintahan, Fakultas Ilmu Sosial dan Ilmu \\ Politik, Universitas Jenderal Achmad Yani, Indonesia
}

\begin{abstract}
Abstrak
Penelitian ini berjudul "Pengaruh Implementasi Kebijakan Pemerintah Daerah Terhadap Efektivitas Perubahan Jaringan Trayek Angkutan Umum Di Kabupaten Cianjur". Latar belakang penelitian ini belum efektifnya implementasi kebijakan pemerintah daerah. Dapat diidentifikasi penelitian ini mengenai implementasi kebijakan, faktor permasalahan, dan upaya yang dilakukan kebijakan dalam pelaksanaan perubahan jaringan trayek angkutan umum di Kabupaten Cianjur. Metodologi penelitian yang digunakan survey explanatif dengan pendekatan kuantitatif. Penelitian ini dilakukan di Kantor Dinas Perhubungan Kabupaten Cianjur,Terminal Rawabango, Terminal Pasirhayam, Pasar Induk, Jalan Siliwangi, Jalan Dr. Muwardi. Pengumpulan data dalam penelitian ini yaitu melalui survey, observasi, dan dokumentasi. Teknik sampling yang digunakan adalah probability sampling dengan simple random sampling. Teori yang digunakan adalah teori implementasi kebijakan dikemukakan oleh Mazmanian serta Sabartier dan untuk teori efektivitas dikemukakan oleh Siagian. Hasil penelitian yang dilakukan menunjukan bahwa tidak ada pengaruh implementasi kebijakan pemerintah daerah terhadap efektivitas perubahan jaringan trayek angkutan umum di Kabupaten Cianjur berbeda dengan teori dari Mazmanian, Sabartier dan Siagian. Ditandai dengan karakterisitik masalah belum dapat teridentifikasi, kemudian daya dukung peraturan dan non peraturan yang dapat mempengaruhi proses pada implementasi belum dapat terlaksanakan dengan baik.
\end{abstract}

Kata Kunci: Implementasi Kebijakan, Efektivitas Perubahan Jaringan Trayek angkutan umum

\begin{abstract}
The title of this research is : "The Effect of Local Government Policy Implementation on the Effectiveness of Changes in the Public Transportation Route Network in Cianjur Regency". The background of this research is the ineffective implementation of local government policy. This research used an explanation survey with a quantitative approach. This research was conducted at the Cianjur Regency Transportation Service Office, Rawabango
\end{abstract}


Terminal, Pasirhayam Terminal, Main Market, Jalan Siliwangi, Jalan Dr. Muwardi. Collecting data in this research is through survey, observation, and documentation. The sampling technique used is probability sampling with simple random sampling. The theory of this research is policy implementation from Mazmanian and Sabartier and for the theory of effectiveness by Siagian. The results of the research showed that there is no affect of the implementation of local government policy on the effectiveness of changes in the network of public transport routes in Cianjur Regency. Marked by the characteristics of the problem can not be identified, then the carrying capacity of regulations and non-regulations that can affect the process of implementation can not be implemented properly.

Keywords: Policy Implementation, Effectiveness of Changes in the Public Transportation Route Network.

\section{PENDAHULUAN}

Penyelenggaraan Pemerintahan Daerah telah diamanatkan dalam Undang-Undang Dasar Negara Republik Indosesia Tahun 1945. Daerah yang diberikan kebebasan untuk mengatur dan mengurus sendiri urusan pemerintahan menurut asas otonom dan tugas pembantuaan. UndangUndang Nomor 23 Tahun 2014 tentang Pemerintahan Daerah merupakan suatu wujud reformasi otonomi daerah dalam rangka meningkatkan efisiensi dan efektivitas penyelenggaraan otonomi daerah untuk memberdayakan daerah dan meningkatkan kesejahteraan rakyat. Penyelenggaraan pemerintahan daerah diarahkan untuk mempercepat terwujudnya kesejahteraan masyarakat melalui peningkatan, pelayanan, pemberdayaan dan peran masyarakat, serta peningkatan daya saing daerah dengan mempertahankan prinsip demokrasi, pemerataan, keadilan dan kekhasan suatu daerah dalam sistem Negara Kesatuan Republik Indonesia.

Perkembangan dinamika dalam sebuah kegiatan masyarakat seirama dengan tuntutan era globalisasi dan otonomi daerah, dengan itu kondisi ketentraman dan ketertiban umum daerah yang kondusif merupakan suatu kebutuhan mendasar bagi seluruh masyarakat umum, yaitu seperti salah satu perangkat daerah Kabupaten Cianjur yang menyelenggarakan 
ketertiban umum khususnya ketertiban transportasi yang dikelola Dinas Perhubungan Kabupaten Cianjur melalui bidang angkutan.

Perkembangan pada suatu kabupaten/kota selalu diiringi dengan peningkatan kebutuhan transportasi salah satunya yaitu angkutan umum. Perekonomian di Kabupaten Cianjur yang meningkat menjadikan mobilitas pergerakan masyarakat Kabupaten Cianjur memerlukan penataan transportasi yang paling mudah yaitu seperti angkutan umum. Angkutan umum merupakan angkutan yang disediakan untuk kepentingan umum dengan sistem bayar. Pada umumnya masyarakat menghendaki adanya pelayanan yang optimal seperti kenyamanan, aman, cepat dan mudah. Dan Dinas Perhubungan juga ikut andil dalam mengelola sistem lalu lintas dan pengelolaan transportasi salah satunya pada bidang angkutan.

Tabel 1

Data Jumlah Angkutan Umum di Kabupaten Cianjur

\begin{tabular}{ccc}
\hline No & Tahun & $\begin{array}{c}\text { Jumlah Angkutan } \\
\text { Umum }\end{array}$ \\
\hline 1. & 2015 & 1002 unit \\
\hline 2. & 2016 & 1376 unit \\
\hline 3. & 2017 & 1637 unit \\
\hline 4. & 2018 & 1689 unit \\
\hline 5. & 2019 & 1516 unit \\
\hline
\end{tabular}

Sumber: Dinas Perhubungan Kabupaten Cianjur 2019

Berkaitan dengan fenomena tersebut munculah permasalahan yaitu kebijakan yang sudah dikeluarkan oleh Pemerintah Daerah Kabupaten 
Cianjur serta dijalankan oleh masyarakat khususnya oleh supir angkutan umum area perkotaan, nyatanya tidak sesuai harapan yang diinginkan dan sangat jauh dari kenyataannya saat di lapangan. Padahal kebijakan tersebut dikeluarkan dengan tujuan yang baik, dan diupayakan untuk meningkatkan mobilitas perekonomian dibidang transportasi khususnya pada supir angkutan umum.

Kebijakan adalah Serangkaian keputusan atau tindakan-tindakan sebagai akibat dari interaksi terstruktur dan berulang diantara berbagai aktor, baik publik/pemerintah maupun privat/swasta yang terlibat berbagai cara dalam merespon, mengidentifikasikan, dan memecahkan suatu masalah yang secara politis didefinisikan sebagai masalah publik (Knoefel, dkk dalam Wahab, 2017). Sementara itu, Mazmanian dan Sabatier dalam (Agustino 2006) mendefinisikan implementasi sebagai pelaksanaan keputusan yang biasanya berbentuk undang-undang, dapat pula berbentuk perintah-perintah atau keputusan-keputusan eksekutif yang penting atau pun keputusan badan peradilan. Lazimnya, keputusan tersebut mengidentifikasikan masalah yang ingin diatasi, menyebutkan secara tegas tujuan atau sasaran yang ingin dicapai dan berbagai cara untuk mengatur pelaksanaannya.

Banyaknya keluhan dari pihak supir angkutan umum karena kebanyakan masyarakat memilih untuk berjalan kaki dan memilih menaiki transportasi online yang disebabkannya rute jaringan trayek yang terlalu lama jarak tempuhnya sehingga rute berputar-putar. Para supir angkutan umum juga merasakan rute jaringan trayek yang semakin jauh dan borosnya bahan bakar, supir angkutan umum mengalami kerugian yang amat besar karena pendapatan yang berkurang dan pengeluaran untuk bahan bakar yang tinggi sehingga hal terserbut sungguh tidak sebanding dengan pendapatan yang didapatkan. Selain itu juga tingkat kemacetan yang semakin tinggi karena beberapa jalan dibuat menjadi satu arah yang 
mengakibatkan angkutan umum mengetem dimana saja untuk mendapatkan penumpang.

Permasalahan-permasalahan tersebut timbul dikarenakan kurang optimalnya kebijakan pemerintah daerah berupa Keputusan Bupati Tentang Jaringan Trayek Dan Alokasi Angkutan Penumpang Umum. Hal tersebut terlihat dari gejala-gejala sebagai berikut:

a) Kejelasan tujuan sudah jelas tetapi belum terarah karena hal ini dilhat dari pengelolaan Dinas Perhubungan Kabupaten Cianjur dalam pelaksanaan tugasnya yaitu pengelolaan pada angkutan umum yang kurang optimal pada perubahan jaringan trayek angkutan umum;

b) Kejelasan strategi, Dinas Perhubungan Kabupaten Cianjur mengalami kesulitan dan sedikit kendala dalam mengatur teknik rute jaringan trayek angkutan umum;

c) Proses analisis dan perumusan kebijakan, yaitu strategi yang telah ditetapkan seharusnya dapat menjembatani tujuan-tujuan yang akan dicapai;

d) Perencanaan kebijakan yang akan dijalankan oleh supir angkutan umum masih mengalami kendala sehingga kurang optimal dalam pelaksanaan kebijakan;

e) Penyusunan kebijakan, rencana yang harus diuraikan dalam kebijakankebijakan yang telah disusun harus terinci;

f) Tersedianya sarana dan prasarana, pemberian sarana dan prasarana yang kurang menunjang terhadap supir angkutan umum.

g) Pelaksanaan efektif dan efisien, sebagaimana dari kejelasan tujuan kebijakan tersebut kurang optimal karena masih ada faktor-faktor permasalahan yang terjadi pada supir angkutan umum dan pada dasarnya dengan diberlakukan kebijakan tersebut sudah efisien karena sebelum perubahan ini masyarakat yang hendak pergi ke tujuan yang cukup jauh harus menaiki angkutan umum sebanyak dua kali tetapi setalah dikeluarkan kebijakan ini menjadi satu kali permasalahan yang terjadi yaitu pada rute jaringan trayek yang lama serta berputar-putar. 
h) Sistem Pengawasan dan pengadilan, yaitu perlu adanya pengawasan dari Dinas Perhubungan terhadap angkutan umum agar terus terpantau saat pelaksanaan kebijakan sehingga tidak menimbulkan permasalahan.

Dalam hal ini diperlukan upaya yang lebih dari pemerintah daerah untuk mencapai efektivitas dari kebijakan yang telah dibuat. Menurut R.M. Streers (Dewi, 2017) efektivitas adalah jangkauan usaha suatu program sebagai suatu sistem dengan sumber daya dan sarana tertentu untuk memenuhi tujuan dan sasarannya tanpan melumpuhkan cara dan sumber daya itu serta tanpa memberi tekanan yang tidak wajar terhadap pelaksanaannya. Sementara itu, menurut (Sedarmayanti, 2009) berpendapat bahwa efektivitas adalah suatu ukuran yang memberikan gambaran seberapa jauh target dapat dicapai. Pengertian efektivitas ini lebih berorientasi kepada keluaran sedangkan masalah penggunaan masukan kurang menjadi perhatian utama. Apabila efisiensi dikaitkan dengan efektivitas maka walaupun terjadi peningkatan efektivitas belum tentu efisien meningkat.

Siagian dalam (Dewi, 2017) berpendapat bahwa efektivitas dapat diukur dari berbagai hal, seperti kejelasan tujuan, kejelasan pencapaian tujuan, proses dan perumusan kebijakan, perencanaan yang lebih baik, penyusunan program, tersedianya sarana dan prasarana kerja, pelaksanaan yang lebih efektif dan efisien, dan system pengawasan dan pengadilan.

Lebih lanjut, berkaitan dengan penelitian ini, adanya sebuah dugaan bahwa implementasi kebijakan pada perubahan jaringan trayek angkutan umum yang kurang optimal karena adanya:

a) Karakterisitik masalah yang terjadi di lapangan seperti kesulitan teknis Dinas Perhubungan Kabupaten Cianjur dalam mengatur perubahan jaringan trayek;

b) Karakterisitik kebijakan seperti sudah jelasnya kebijakan atas Keputusan Bupati pada perubahan jaringan trayek angkutan umum tetapi saat sudah dijalankan belum optimal;

c) Variabel lingkungan, kurangnya sosialisasi dan komunikasi antara Dinas Perhubungan Kabupaten Cianjur dan supir angkutan umum. 
Dengan demikian, penelitian ini akan fokus membahas terkait "Pengaruh Implementasi Kebijakan Pemerintah Daerah Terhadap Efektivitas Perubahan Jaringan Trayek Angkutan Umum di Kabupaten Cianjur”.

\section{METODE PENELITIAN}

Penelitian ini menggunakan metode survey explanatory atau survey explanatif dengan pendekatan kuantitatif. Menurut Kerlinger dalam (Sugiyono, 2018) menyatakan bahwa: "Metode survey adalah metode penelitian yang dilakukan dengan mempelajari data dari sampel yang diambil dari sebuah populasi, sehingga ditemukan kejadian-kejadian relatif, distribusi dan hubungan antar variabel". Metode survey memiliki kegunaan untuk menjelaskan hubungan kausalitas antar dua variabel melalui pengujian hipotesis. Peneliti menggunakan survey karena mempunyai tujuan guna menunjukan pengaruh variabel implementasi kebijakan Pemerintah Daerah terhadap variabel efektivitas perubahan jaringan trayek angkutan umum.

Penelitian ini dilakukan di Kantor Dinas Perhubungan Kabupaten Cianjur, Terminal Rawabango, Terminal Pasirhayam, Pasar Induk, Jalan Siliwangi, Jalan Dr. Muwardi. Pengumpulan data dalam penelitian ini yaitu melalui survey, observasi, dan dokumentasi. Teknik sampling yang digunakan adalah probability sampling dengan simple random sampling (Sugiyono, 2018). Populasi pada penelitian ini dikategorikan berdasarkan status pekerjaan, serta pihak-pihak yang terkait, yaitu jumlah pegawai Dinas Perhubungan Kabupaten Cianjur sejumlah 243 orang dan jumlah angkutan umum area perkotaan sejumlah 1516 angkutan. Jumlah sample dalam penelitian ini setelah dihitung menggunakan rumus Slovin adalah 95 responden.

Teknik analisis data yang digunakan adalah teknik analisis deskriptif dan teknik analisis inferensial. Teknik analisis deskriptif digunakan untuk menyajikan data menggunakan tabel dan perhitungan persentase. Teknik inferensial menurut (Sugiyono, 2018) adalah "teknik statistik yang 
digunakan untuk menganalisis data sampel dan hasilnya diberlakukan untuk populasi”. Metode analisis data yang digunakan dalam penelitian ini adalah regresi linear sederhana. Gagasan perhitungan yang ditetapkan oleh sir Francis Galton (1822-1911) ini dapat digunakan untuk melihat pengaruh variabel penjelas atau variabel bebas terhadap variabel tak bebas.

\section{HASIL DAN PEMBAHASAN}

Analisis data penelitian yang digunakan menggunakan statistik inferensial yaitu analisis data dari sample yang nantinya ditarik sebuah opini atau kesimpulan sehingga perbedaan mendasarnya terletak pada hasil dari analisis yang disajikannya. Cara perhitungan pengkategorian variabel dan dimensi berdasarkan data yang diperoleh, kemudian disusun ke dalam tabel tunggal yang dikategorikan dan disajikan dengan menggunakan pendekatan distribusi frekuensi.

Untuk mengetahui, mendeskripsikan dan menganalisa secara keseluruhan yaitu bagaimana implementasi kebijakan pemerintah daerah di Kabupaten Cianjur maka dapat dilihat pada tabel hasil rekapitulasi skor dibawah ini:

Tabel 2

Rekapitulasi Skor Jawaban Variabel Implementasi Kebijakan Pemerintah Daerah

\begin{tabular}{clcccc}
\hline No & \multicolumn{1}{c}{ Dimensi } & Skor & $\begin{array}{l}\text { Ideal } \\
\text { Skor }\end{array}$ & Keterangan \\
\hline 1 & $\begin{array}{l}\text { Mudah atau } \\
\text { Tidaknya Masalah } \\
\text { yang akan }\end{array}$ & 803 & 1900 & 42,26 & Kurang Baik \\
Digarap & & & & \\
\hline 2 & $\begin{array}{l}\text { Kemampuan } \\
\text { Kebijakan- } \\
\text { kebijakan } \\
\text { Menstruktur }\end{array}$ & 1552 & 3325 & 46,68 & Kurang Baik \\
& & & & \\
Proses & & & & \\
Implementasi & & & & \\
& Secara Tepat & & & & \\
\hline
\end{tabular}




\begin{tabular}{llllll}
\hline 3 & $\begin{array}{l}\text { Variabel-variabel } \\
\text { di Luar Undang- } \\
\text { undang yang } \\
\text { mempengaruhi } \\
\text { Implementasi }\end{array}$ & & & & \\
& & & & \\
& & & & \\
\hline 4 & $\begin{array}{l}\text { Tahapan dalam } \\
\text { Proses } \\
\text { Implementasi }\end{array}$ & 1182 & 2375 & 49,77 & Kurang Baik \\
Kebijakan & & & & \\
Total Skor & 4885 & 9975 & 48,97 & Kurang Baik \\
\hline
\end{tabular}

Sumber : Pengolahan Data Peneliti 2020

Berdasarkan hasil rekapitulasi di atas telah diketahui bahwa implementasi kebijakan pemerintah daerah di Kabupaten Cianjur memiliki perolehan dari setiap dimensinya yaitu:

a) Mudah atau Tidaknya Masalah yang akan Digarap, memiliki skor $42,26 \%$ yang artinya kurang baik

b) Mudah atau Tidaknya Masalah yang akan Digarap, memiliki skor 46,68\% yang artinya kurang baik

c) Variabel-variabel di Luar Undang-undang yang mempengaruhi Implementasi, memiliki skor 56,76\% yang artinya cukup baik

d) Tahapan dalam Proses Implementasi Kebijakan, memiliki skor 49,77\% yang artinya kurang baik

Telah dijumlahkan dari ke empat dimensi tersebut memiliki skor 48,97\% yang artinya masuk dalam kategori kurang baik berada pada kisaran rentang skor 36,01-52,00. Artinya implementasi kebijakan pemerintah daerah di Kabupaten Cianjur yang dijalankan menurut pandangan serta tanggapan responden adalah belum sepenuhnya menunjukan hasil yang sesuai harapan. Dari empat dimensi yang mengukur variabel ini diketahui aspek variabel-variabel di luar undang- 
undang yang mempengaruhi implementasi yang mendapatkan penilaian paling tinggi serta aspek mudah atau tidaknya masalah yang akan digarap merupakan penilainya yang paling rendah penilaiannya.

Untuk mengetahui, mendeskripsikan dan menganalisa secara keseluruhan yaitu bagaimana efektivitas perubahan jaringan trayek angkutan umum di Kabupaten Cianjur maka dapat dilihat pada tabel hasil rekapitulasi skor dibawah ini.

Tabel 3

Rekapitulasi Skor Jawaban Variabel Efektivitas Perubahan Jaringan Trayek Angkutan

\begin{tabular}{cccccc}
\hline No & Indikator & Skor & $\begin{array}{c}\text { Ideal } \\
\text { Skor }\end{array}$ & $\%$ & Keterangan \\
\hline 1 & $\begin{array}{l}\text { Kejelasan isi tujuan } \\
\text { yang akan dicapai }\end{array}$ & 284 & 475 & 59,79 & Cukup Baik \\
\hline 2 & $\begin{array}{l}\text { Kejelasan strategi } \\
\text { pencapaian tujuan }\end{array}$ & 241 & 475 & 50,74 & Kurang Baik \\
\hline 3 & Proses analisis dan & 235 & 475 & 49,47 & Kurang Baik \\
& perumusan kebijakan & & & & \\
\hline 4 & Perencanaan & 244 & 475 & 51,37 & Kurang Baik \\
\hline 5 & Penyusunan Kebijakan & 246 & 475 & 51,79 & Kurang Baik \\
\hline 6 & $\begin{array}{l}\text { Tersedianya sarana dan } \\
\text { prasarana }\end{array}$ & 223 & 475 & 46,95 & Kurang Baik \\
\hline 7 & $\begin{array}{l}\text { Pelaksanaan yang } \\
\text { efektif dan efisien }\end{array}$ & 214 & 475 & 45,05 & Kurang Baik \\
\hline 8 & $\begin{array}{l}\text { Sistem pengawasan dan } \\
\text { pengadilan }\end{array}$ & 269 & 475 & 56,63 & Cukup Baik \\
\hline Total Skor & 1956 & 3800 & 51,47 & Kurang Baik \\
\hline
\end{tabular}

Sumber: Hasil Olahan Peneliti 2020 
Berdasarkan hasil rekapitulasi di atas telah diketahui bahwa efektivitas perubahan jaringan trayek angkutan di Kabupaten Cianjur memiliki perolehan dari setiap dimensinya yaitu:

a) Kejelasan isi tujuan yang akan dicapai, memiliki skor 59,76\% yang artinya cukup baik;

b) Kejelasan strategi pencapaian tujuan, memiliki skor 50,74\% yang artinya kurang baik;

c) Proses analisis dan perumusan kebijakan, memiliki skor 49,47\% yang artinya kurang baik;

d) Perencanaan, memiliki skor 51,37\% yang artinya kurang baik;

e) Penyusunan Kebijakan, memiliki skor 51,79\% yang artinya kurang baik;

f) Tersedianya sarana dan prasarana, memiliki skor 46,95\% yang artinya kurang baik;

g) Pelaksanaan yang efektif dan efisien, memiliki skor 45,06\% yang artinya kurang baik;

h) Sistem pengawasan dan pengadilan, memiliki skor 56,63\% yang artinya cukup baik.

Telah dijumlahkan dari ke delapan dimensi skor $51,47 \%$ yang artinya masuk dalam kategori kurang baik berada pada kisaran rentang skor 36,01-52,00. Artinya efektivitas perubahan jaringan trayek angkutan di Kabupaten Cianjur yang dijalankan menurut pandangan serta tanggapan responden adalah belum sepenuhnya menunjuka

Untuk mengetahui pengaruh yang terjadi antara implementasi kebijakan pemerintah daerah terhadap efektivitas perubahan jaringan trayek angkutan umum di Kabupaten Cianjur yang terdiri dari uji normalitas, persamaan regresi linear sederhana, analisis korelasi pearson, 
analisis koefisien determinasi, dan pengujian hipotesis, secara simultan memiliki tidak ada pengaruh yang signifikan antara implementasi kebijakan pemerintah daerah terhadap efektivitas perubahan jaringan trayek angkutan umum, dengan kata lain kita dapat mempercayai 95\% terbukti bahwa implementasi kebijakan pemerintah daerah berpengaruh terhadap efektivitas perubahan jaringan trayek angkutan umum di kabupaten Cianjur.

Penelitian ini dilakukan untuk mengetahui pengaruh yang terjadi antara implementasi kebijakan pemerintah daerah terhadap efektivitas perubahan jaringan trayek angkutan umum di Kabupaten Cianjur yang terdiri dari uji normalitas, persamaan regresi linear sederhana, analisis korelasi pearson, analisis koefisien determinasi, dan pengujian hipotesis. Data hasil penyebaran kuesioner yang bersifat skala pengukuran ordinal dikonversi menjadi skala pengukuran interval dengan bantuan metode MSI (Method of Successive Interval).

\section{Uji Normalis}

Uji normalitas pada model regresi adalah pengujian data yang bertujuan untuk menganalisa dan mengetahui apakah suatu data variabel dependen ataupun independen yang terdiri dari butir- butir pertanyaan berdistribusi normal atau tidak. Suatu data dikatakan memiliki penyebaran/berdistribusi normal, jika penyebaran datanya mengikuti garis diagonal dari kiri bawah, ke kanan atas. Pada penelitian ini akan dilihat persebaran data implementasi kebijakan pemerintah daerah departement front office (independent variable) dan efektivitas perubahan jaringan trayek angkutan umum (dependent variable). Penulis melakukan uji normalitas dengan bantuan software SPSS 16.0 for windows. Namun, terlebih dahulu penulis merubah data yang sebelumnya berskala ordinal menjadi data berskala interval dengan menggunakan Method of Succesive Interval (MSI). Berikut grafik p-plot hasil pengolahan data statistik yang ditunjukkan pada gambar berikut: 
Kurva Uji Normalitas

Normal P-P Plot of Regression Standardized Residual

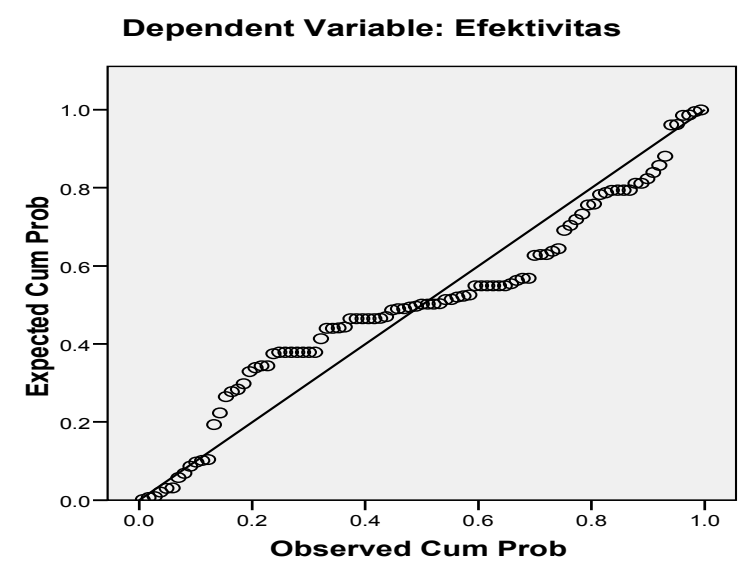

Sumber: Hasil Pengolahan Data Menggunakan program SPSS 16.0, 2020

Pada Gambar 1 dapat diketahui bahwa data menyebar terlihat di sekitar garis diagonal dan mengikuti arah garis diagonal tersebut, maka model regresi menunjukan bahwa persyaratan normalitas telah terpenuhi.

\section{Analisis Regresi Linier Sederhana}

Analisis ini dimaksudkan untuk mengetahui adanya pengaruh antara variabel implementasi kebijakan pemerintah daerah (X) terhadap variabel efektivitas perubahan jaringan trayek angkutan umum (Y). Tujuannya untuk meramalkan atau memperkirakan nilai variabel dependen dalam hubungannya dengan nilai variabel lain. Dari hasil perhitungan dengan menggunakan SPSS 16.0 maka diperoleh output dan persamaan hubungan regresi sederhana sebagai berikut:

Tabel 4

Hasil Analisis Regresi Linier Sederhana

Coefficients $^{\mathrm{a}}$

\begin{tabular}{|c|c|c|c|c|c|c|}
\hline \multirow{2}{*}{\multicolumn{2}{|c|}{ Model }} & \multicolumn{2}{|c|}{$\begin{array}{l}\text { Unstandardized } \\
\text { Coefficients }\end{array}$} & \multirow{2}{*}{$\begin{array}{c}\begin{array}{c}\text { Standardized } \\
\text { Coefficients }\end{array} \\
\text { Beta } \\
\end{array}$} & \multirow[b]{2}{*}{$\mathrm{t}$} & \multirow[b]{2}{*}{ Sig. } \\
\hline & & B & Std. Error & & & \\
\hline & (Constant) & 4.887 & 1.648 & & 2.965 & .004 \\
\hline & Implementasi Kebijakan & .383 & .029 & .809 & 13.287 & .000 \\
\hline
\end{tabular}

a. Dependent Variable: Efektivitas

Sumber: Hasil Pengolahan Data Menggunakan Program SPSS 16.0, 2020 


$\begin{array}{ll}\text { Unstandardized coefficients }= & \text { data tidak terstandarisisai dengan standar } \\ & \text { deviasi } \\ \text { Standardized coefficients } & \text { data telah distandarisasi dengan standar } \\ & \text { deviasi } \\ = & \text { nilai } \mathrm{t} \text { statistik } \\ \mathrm{t} & =\text { tingkat signifikansi } \\ \text { sig } & =\text { standar error pada koefisien regresi } \\ \text { std. Error } & =\text { Variabel Y ketika X dianggap } 0 \\ \text { Constant } & =\text { Variabel X } \\ \mathrm{X} & \end{array}$

Berdasarkan tabel 4 di atas diperoleh nilai a sebesar 4,887 dan nilai b sebesar 0,383. Model regresi yang digunakan adalah: $\mathrm{Y}=\mathrm{a}+\mathrm{bX}$

Dimana : $\mathrm{Y}=$ Efektivitas perubahan jaringan trayek angkutan umum

$$
\begin{array}{ll}
\mathrm{A} & =\text { Nilai intersep (konstanta) } \\
\mathrm{X} & =\text { Implementasi kebijakan pemerintah daerah } \\
\mathrm{B} & =\text { KoefisienRegresi }
\end{array}
$$

Maka dapat dibuat suatu persamaan regresi sebagai berikut:

$$
\mathrm{Y}=4,887+0,383 \mathrm{X}
$$

Dari pernyataan di atas, dapat disimpulkan bahwa setiap kenaikan variabel X (implementasi kebijakan pemerintah daerah) sebesar 1 satuan akan berpengaruh kepada kenaikan variabel Y (efektivitas perubahan jaringan trayek angkutan umum) sebesar 0,383 satuan dan variabel Y akan bernilai 4,887 apabila variabel X bernilai 0 (nol). Jadi, setiap implementasi kebijakan pemerintah daerah makin tinggi itu akan meningkatkan 0,383 poin efektivitas perubahan jaringan trayek angkutan umum.

\section{Koefisien Determinasi}


Analisis ini dilakukan untuk melihat seberapa besar pengaruh variabel implementasi kebijakan pemerintah daerah (X) terhadap variabel efektivitas perubahan jaringan trayek angkutan umum $(\mathrm{Y})$, dengan rumus :

$$
\mathrm{KD}=\left(r_{x y}\right)^{2} \times 100 \%
$$

$\mathrm{KD}=$ koefisien determinasi

$\left(\mathrm{r}_{\mathrm{xy}}\right)^{2}=$ koefisien korelasi product moment

Maka :

$$
\begin{aligned}
\mathrm{KD} & =r_{\mathrm{yx}}{ }^{2} \times 100 \% \\
= & (0,809)^{2} \times 100 \% \\
= & 65,5 \%
\end{aligned}
$$

Berdasarkan output di atas, terlihat bahwa nilai koefisien determinasi sebesar 65,5\%. Hal ini menunjukkan bahwa besar pengaruh implementasi kebijakan pemerintah daerah (X) terhadap variabel efektivitas perubahan jaringan trayek angkutan umum (Y) adalah sebesar 65,5\%. Pengaruh selebihnya, sebesar 34,5\% merupakan pengaruh oleh faktor-faktor lain yang tidak diteliti dalam penelitian ini. Faktor implementasi kebijakan pemerintah daerah memiliki proporsi yang tinggi dalam mempengaruhi efektivitas perubahan jaringan trayek angkutan umum karena lebih dari setengah dari faktor efektivitas perubahan jaringan trayek angkutan umum di Kabupaten Cianjur (65,5\%), sementara 34,5\% dibagi kedalam faktorfaktor lainnya yang tidak diteliti dalam penelitian ini.

\section{Pengujian Hipotesis Uji (t)}

Setelah diperoleh model regresi linier sederhana, koefisien korelasi dan koefisien determinasi, maka kemudian dilakukan pengujian hipotesis untuk menguji apakah terdapat pengaruh yang signifikan atau tidak antara kedua variabel dengan menggunakan uji-t sebagai berikut:

$\mathrm{H}_{\mathrm{o}}$ : Artinya implementasi kebijakan pemerintah daerah tidak memberikan pengaruh yang signifikan terhadap efektivitas perubahan jaringan trayek angkutan umum. 
$\mathrm{H}_{\mathrm{a}} \quad$ : Artinya implementasi kebijakan pemerintah daerah memberikan pengaruh yang signifikan terhadap efektivitas perubahan jaringan trayek angkutan umum.

Menggunakan program SPSS 16.0 didapat output sebagai berikut:

Tabel 5

Output Pengujian Uji Hipotesis

Coefficients $^{\mathrm{a}}$

\begin{tabular}{|c|c|c|c|c|c|}
\hline \multirow[b]{2}{*}{ Model } & \multicolumn{2}{|c|}{$\begin{array}{c}\text { Unstandardized } \\
\text { Coefficients }\end{array}$} & \multirow{2}{*}{$\begin{array}{c}\text { Standardized } \\
\text { Coefficients } \\
\text { Beta } \\
\end{array}$} & \multirow[b]{2}{*}{$\mathrm{t}$} & \multirow[b]{2}{*}{ Sig. } \\
\hline & B & Std. Error & & & \\
\hline (Constant) & 4.887 & 1.648 & & 2.965 & .004 \\
\hline Implementasi Kebijakan & .383 & .029 & .809 & 13.287 & .000 \\
\hline
\end{tabular}

a. Dependent Variable: Efektivitas

Sumber: Hasil Pengolahan Data Menggunakan program SPSS 16.0, 2020

Dari hasil pengolahan SPSS di atas didapat nilai thitung sebesar 13,287. Dengan alpha $(\mathrm{a})=5 \%$ dan derajat kebebasan $(\mathrm{dk})=\mathrm{n}-2=93$, maka berdasarkan tabel distribusi-t dua pihak didapat nilai tabel sebesar 1,986. Kemudian nilai thitung dan tabel tersebut kemudian diuji menggunakan kriteria pengujian hipotesis sebagai berikut:

Jika $t_{\text {hitung }} \geq t_{\text {tabel }}$ atau $-t_{\text {hitung }} \leq-t_{\text {tabel }}$, maka $H_{0}$ ditolak.

Jika $t_{\text {hitung }}<t_{\text {tabel }}$ atau $-t_{\text {hitung }}>-t_{\text {tabel }}$, maka $\mathrm{H}_{0}$ diterima.

Gambar 2

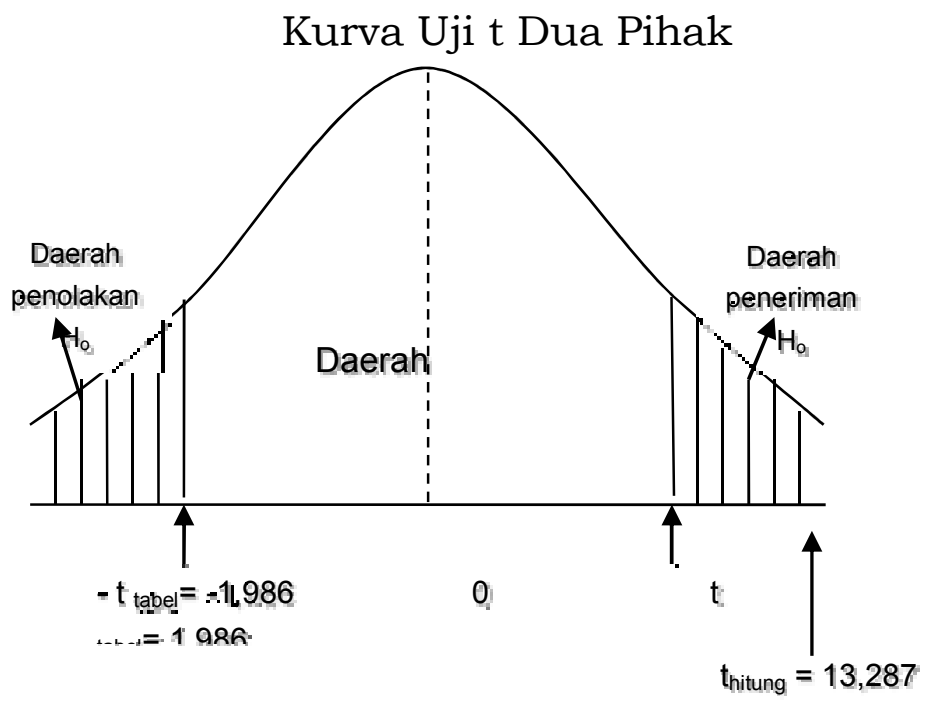


Dikarenakan nilai thitung lebih besar daripada tabel $(13,287>1,986)$ maka $\mathrm{H}_{0}$ ditolak dan $\mathrm{H}_{\mathrm{a}}$ diterima. Hal ini menunjukkan adanya pengaruh yang signifikan antara implementasi kebijakan pemerintah daerah terhadap efektivitas perubahan jaringan trayek angkutan umum, dengan kata lain kita dapat mempercayai 95\% terbukti bahwa implementasi kebijakan pemerintah daerah berpengaruh terhadap efektivitas perubahan jaringan trayek angkutan umum di kabupatn Cianjur.

\section{KESIMPULAN}

Kesimpulan yang dapat diambil dari penelitian ini yaitu, berdasarkan hasil perhitungan tabulasi skor total, variabel implementasi kebijakan pemerintahan daerah berada pada kategori kurang baik. Hal tersebut dapat dilihat dari variabel implementasi kebijakan pemerintahan daerah diperoleh nilai presentase skor sebesar 48,97 persen karena berada dalam interval skor 36,01-52,00 ini artinya bahwa implementasi kebijakan pemerintah daerah di Kabupaten Cianjur yang dijalankan menurut pandangan serta tanggapan responden adalah belum sepenuhnya menunjukan hasil yang sesuai harapan. Dari empat dimensi yang mengukur variabel ini diketahui aspek variabel-variabel di luar undang-undang yang mempengaruhi implementasi yang mendapatkan penilaian paling tinggi serta aspek mudah atau tidaknya masalah yang akan digarap merupakan penilainya yang paling rendah penilaiannya.

Berdasarkan hasil perhitungan tabulasi skor total, variabel efektifitas perubahan jaringan trayek angkutan umum berada pada kategori kurang baik. Hal tersebut dapat dilihat dari seluruh variabel efektifitas diperoleh hasil akhir sebesar 51,47 karena berada dalam interval skor 36,01-52,00 ini 
artinya efektivitas perubahan jaringan trayek angkutan di Kabupaten Cianjur yang dijalankan menurut pandangan serta tanggapan responden adalah belum sepenuhnya menunjukan hasil yang sesuai harapan. Dari delapan indikator yang mengukur variabel ini diketahui aspek kejelasan strategi pencapaian tujuan yang mendapatkan penilaian paling tinggi serta aspek Pelaksanaan yang efektif dan efisien merupakan penilainya yang paling rendah penilaiannya.

Berdasarkan perhitungan, terlihat bahwa nilai koefisien determinasi sebesar 65,5\%. Hal ini menunjukkan bahwa besar pengaruh implementasi kebijakan pemerintah daerah (X) terhadap variabel efektivitas perubahan jaringan trayek angkutan umum (Y) adalah sebesar 65,5\%. Pengaruh selebihnya, sebesar $34,5 \%$ merupakan pengaruh oleh faktor-faktor lain yang tidak diteliti dalam penelitian ini. Faktor implementasi kebijakan

pemerintah daerah memiliki proporsi yang tinggi dalam mempengaruhi efektivitas perubahan jaringan trayek angkutan umum karena lebih dari setengah dari faktor efektivitas perubahan jaringan trayek angkutan umum di Kabupaten Cianjur (65,5\%), sementara 34,5\% dibagi kedalam faktorfaktor lainnya yang tidak diteliti dalam penelitian ini.

\section{DAFTAR PUSTAKA}

Agustino, L. (2006). Dasar-Dasar Kebijakan Publik. Bandung: Alfabeta.

Data Primer penelitian (2020)

Dewi, N. U. (2017). Efektivitas Pelayanan Transportasi Publik (Studi Kasus: Mamminasata). Makasar: Universitas Hasanuddin.

Dinas Perhubungan Kabupaten Cianjur (2019) 
Sedarmayanti. (2009). Sumber Daya Dan Produktivitas Kerja. Bandung: Mandar Maju.

Sugiyono. (2018). Metode Penelitian Kuantitatif. Bandung: Alfabeta.

Undang-Undang Dasar Republik Indonesia Tahun 1945

Undang-Undang Nomor 23 Tahun 2014 Tentang Pemerintahan Daerah

Wahab, S. A. (2017). Analisis Kebijakan Dari FormulasI Kepenyusunan Model-Model Implementasi Kebijakan Publik. Jakarta: PT Bumi Aksara. 